\title{
Rare form of salmonellosis
}

INSERM

\section{Source}

INSERM. (1999). Orphanet: an online rare disease and orphan drug data base. Rare form of salmonellosis. ORPHA:795

Salmonellosis is an infection of salmonella, which are mobile flagellated gram-negative bacteria belong ing to the enterobacteria family. Two nosological groups should be disting uished: typhoid fever due to S. typhi and S. paratyphi A, B and C, and salmonelloses themselves. 